\title{
Quality of groundwater resources in Afghanistan
}

\author{
Ehsanullah Hayat • Alper Baba
}

Received: 2 September 2016 / Accepted: 30 May 2017 /Published online: 6 June 2017

(C) Springer International Publishing Switzerland 2017

\begin{abstract}
Water is the main source of energy production and economy in Afghanistan where agriculture accounts for more than $50 \%$ of the country's gross domestic product (GDP). Access to safe drinking water is still a problem in the country, which has caused different health issues and even child mortality especially in rural areas. Groundwater is the main source of drinking water in the country. However, little knowledge is available about the quality of groundwater throughout the entire country, and its quality has not been investigated extensively yet like in other countries in the world. While most people think that consuming groundwater is a reliable and safe source of drinking water for health, the United Nations (UN) agencies report various kinds of waterborne diseases and even child mortalities due to drinking water quality in the country. In this article, significant geogenic and anthropogenic factors that play a vital role in groundwater contamination of the country are identified and explained. Different geogenic contaminations such as arsenic, fluoride, sulfate, and boron occur in several areas of Afghanistan that have a direct effect on human health. The water quality mapping for Afghanistan is
\end{abstract}

\section{E. Hayat}

Dept. Civil Engineering, Helmand University, Lashkar Gah, Helmand 3901, Afghanistan

e-mail: ehsanhaqiqat@yahoo.com

E. Hayat · A. Baba $(\bowtie)$

Dept. Civil Engineering, Izmir Institute of Technology,

35430 Urla, İzmir, Turkey

e-mail: alperbaba@iyte.edu.tr completed for half of the country, which shows that groundwater is plagued by high levels of fluoride and arsenic in some areas. The water quality mapping of the other half of the country cannot be completed due to security concerns currently. Also, there are different kinds of waterborne diseases such as diarrhea, cholera, and dysentery that can be seen in different parts of the country because of anthropogenic activities which continuously deteriorate groundwater.

Keywords Arsenic Contamination - Groundwater. Health · Afghanistan

\section{Introduction}

Afghanistan is a landlocked mountainous country with a total area of $652,000 \mathrm{~km}^{2}$ and a population of around 32 million, located within south and central Asia between the latitudes of $29^{\circ} 21^{\prime} \mathrm{S}$ to $38^{\circ} 30^{\prime} \mathrm{N}$ and longitudes of $60^{\circ} 31^{\prime}$ $\mathrm{W}$ to $75^{\circ} 00^{\prime} \mathrm{E}$ (Fig. 1). Approximately, 10-12\% of country's land is arable that is about 6.5-7.8 million ha. The country's climate is arid to semi-arid where the weather is cold in winter and hot and dry in summer with temperature that ranges from $-20{ }^{\circ} \mathrm{C}$ in winter to $50{ }^{\circ} \mathrm{C}$ in summer. The annual precipitation in Afghanistan varies according to region, ranging from $75 \mathrm{~mm}$ in the southwest up to $1270 \mathrm{~mm}$ in the northeast with an average annual precipitation of $300 \mathrm{~mm}$ (JCA, 2011). A considerable drought occurred between 1999 and 2003 and in the last three decades while the number of karez wells decreased from 6781 to 686 in this period (Habib, 2014). A karez 


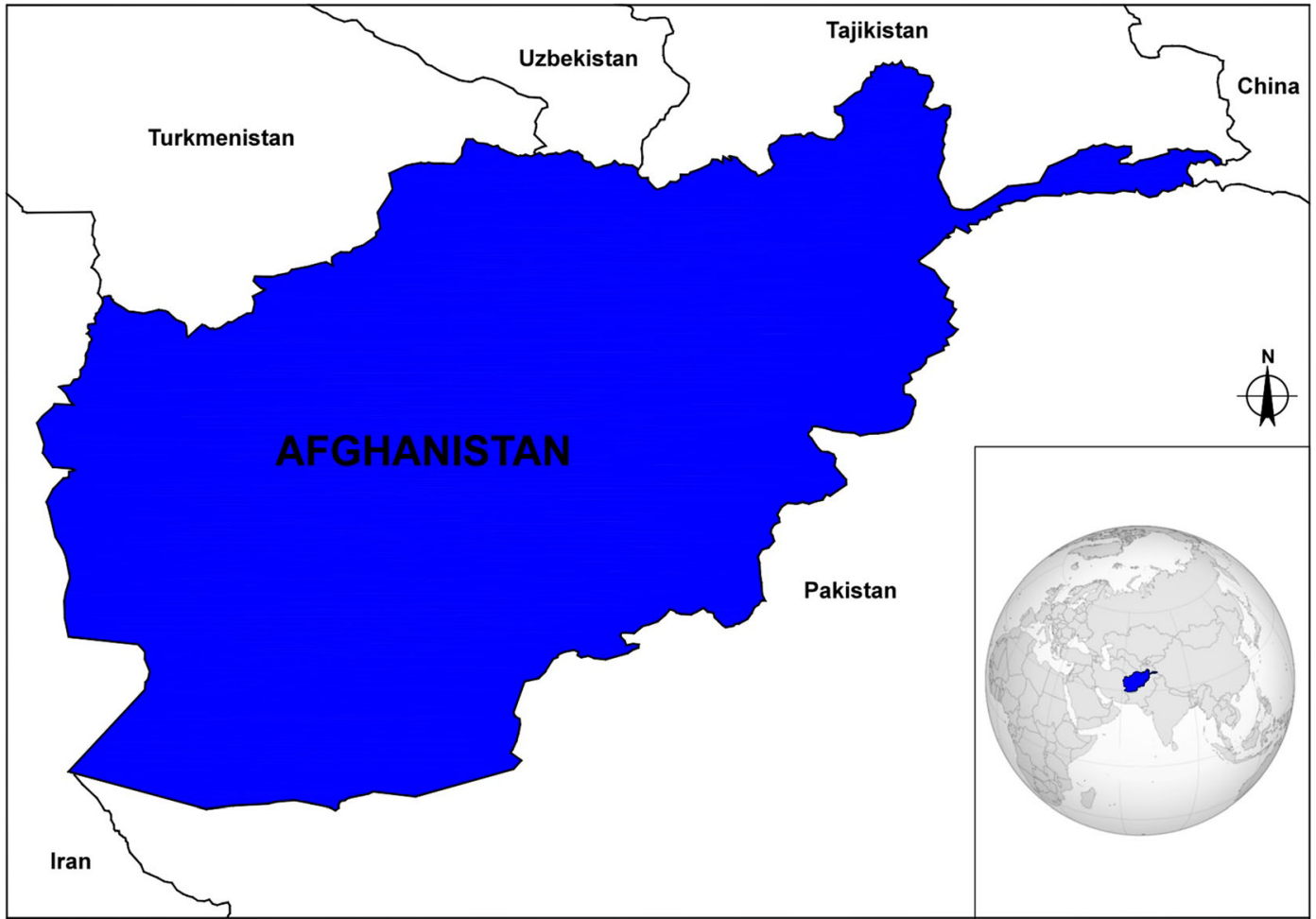

Fig. 1 Location map of Afghanistan

well is an ancient irrigation system consisting of a tunnel dug at a very slight upward gradient into rising ground so that water from deep within the earth runs out to the surface. The length of the karez wells varies with the geographical environment. Karez is like qanats that were used in Persia and the Middle East, which is an old system of water supply from a deep well with a series of vertical access shafts. According to the Ministry of Energy and Water (MEW, 2016) of Afghanistan, long-term total annual precipitation in Afghanistan is 164 billion $\mathrm{m}^{3}$, evaporation is 87 billion $\mathrm{m}^{3}$ ( $53 \%$ of the total annual precipitation), groundwater recharge is 16 billion $\mathrm{m}^{3}$ (10\% of the total annual precipitation), surface water runoff is 61 billion $\mathrm{m}^{3}$ ( $37 \%$ of the total annual precipitation), and the total annual available water resources are 77 billion $\mathrm{m}^{3}$ (Table 1).

For a sustainable and stable development, water is a critical factor in Afghanistan as it is the most important resource and the main source of energy production. The importance of water is well recognized where agriculture accounts for more than $50 \%$ of the country's GDP and without water, agriculture would not exist. Ahmad and Wasiq (2004) indicated that more than $93 \%$ of water

Table 1 Annual precipitation data by basin in Afghanistan (MEW, 2016)

\begin{tabular}{lllll}
\hline Basin & $\begin{array}{l}\text { Area } \\
\left(\mathrm{km}^{2}\right)\end{array}$ & $\begin{array}{l}\text { Annual average } \\
\text { precipitation }(\mathrm{mm})\end{array}$ & $\begin{array}{l}\text { Total precipitation } \\
\text { (billion m } \text { m }^{\text {year })}\end{array}$ & $\begin{array}{l}\% \text { of total } \\
\text { precipitation }\end{array}$ \\
\hline Kabul & $108,392.00$ & 298 & 32.3 & 20 \\
Helmand & $202,006.00$ & 180 & 36.36 & 22 \\
Amu & $101,498.00$ & 393 & 39.889 & 24 \\
North & $78,099.00$ & 268 & 20.93 & 13 \\
Harirod & $162,659.00$ & 210 & 34.16 & 21 \\
Total & $652,654.00$ & 270 & 163.64 & 100 \\
\hline
\end{tabular}


is used for irrigation in the country, but Ansari (2014) even reports it as $99 \%$ of the total water used annually. The water being used with a huge amount for agriculture is substantially wasted due to weak and traditional irrigation practices. The Afghanistan National Development Strategy (ANDS, 2008) indicates that more than $50 \%$ of the irrigation water is used in surplus and unfortunately wasted. Additionally, more than $15 \%$ of the agricultural land is being irrigated by groundwater in karez wells fed by springs and shallow wells. The total cultivated land is approximately 3.9 million ha, of which, 2.6 million ha is irrigated and 1.3 million ha is rainfed (Qureshi, 2002). About $85 \%$ of the labor force is employed in the agriculture sector (Ahmad and Wasiq, 2004). The annual use of water for irrigation is estimated to be 26.8 billion $\mathrm{m}^{3}$ (MEW, 2016). According to JICA (2011), one million ha of the land was cultivated in 2003 with irrigation facilities, while Mahmoodi (2008) argues that Afghanistan's irrigated land has decreased from 3.3 million ha in 1980 to 1.8 million ha in 2008 , which has had a direct effect on the economy of the country.

Access to safe drinking water is still a problem in the country, which has caused different health issues and even child mortality especially in rural areas. According to Qureshi (2002), only 24\% of the total population have access to safe drinking water, while Saffi and Kohistani (2013) claim that on a national level, only $27 \%$ of the population has access to safe drinking water. Considering that $27 \%$ of the country's population has access to safe drinking water, this percentage is still very low and the drinking water quality has to be improved. Although Afghanistan has enough available water resources at the present, there will be still some issues in the future due to the population increase and climate changes. Moreover, in addition to the improvement of the quality of drinking water, it has to be used systematically within a managed framework. Therefore, it is essential for the government to adopt water resources management strategies and apply them right away. Vining and Vecchia (2007) anticipate a $10 \%$ reduction in the total annual precipitation during the next 50 years in Afghanistan. Also, snowmelts will occur earlier during the year because of the surface temperature increment in mountainous regions (Mack et al., 2010a).

Some studies about the quality of groundwater have been conducted by the Danish Committee for Aid to Afghan Refugees (DACAAR) and the United States Geological Survey (USGS) in Afghanistan. DACAAR has worked for more than two decades in Afghanistan providing drinking water through bore wells equipped with hand pumps for the rural population of the country. The Afghan Ministry of Rural Rehabilitation and Development (MRRD) is also a major actor providing drinking water to the rural population through the National Solidarity Program (NSP) but DACAAR has undertaken investigations into groundwater quality, which is our topic of interest here. It should be noted that groundwater is the main source of drinking water throughout the country. Little knowledge is available about the quality of groundwater countrywide. Therefore, the aim of this study is to extensively review the existing literature, evaluate groundwater resources and their quality, reanalyze some existing raw data from the literature and available reports, categorize and address the major factors that deteriorate groundwater in the country, and finally recommend some future investigations and remedial actions for groundwater quality in the country.

\section{Geological characteristics of Afghanistan}

The geology and tectonics of Afghanistan are significantly complicated (Fig. 2). The country is located within the range of the great tectonic upheaval that has produced the world's highest mountain ranges such as the Hindu Kush, Pamir, Karakoram, and Himalaya (Broshears et al., 2005). Afghanistan's geology includes Proterozoic metamorphic rocks, Paleozoic metamorphic and sedimentary rocks, basic igneous rocks, acidic igneous rocks, volcanic rocks, Paleocene sedimentary rocks, Cretaceous-Paleocene sedimentary rocks, Triassic sedimentary rocks, Cretaceous sedimentary rocks, Neogene sedimentary rocks, Jurassic sedimentary rocks, Permian-Triassic sedimentary rocks, and Quaternary sediments. Tünnermeier and Houben (2005) determined that the Kabul Basin formed by plate movements occurring during the Late Paleocene with metamorphic rocks surrounding the basin. Based on the tectonic origin, the Helmand basin is a structurally closed and large basin that started to form during the middle Tertiary because of the collision of numerous former Gondwanaland fragments (Whitney, 2006). Karstic and jointed aquifers are observed in different parts of the region where geological and tectonic factors have affected groundwater aquifers in the country. 


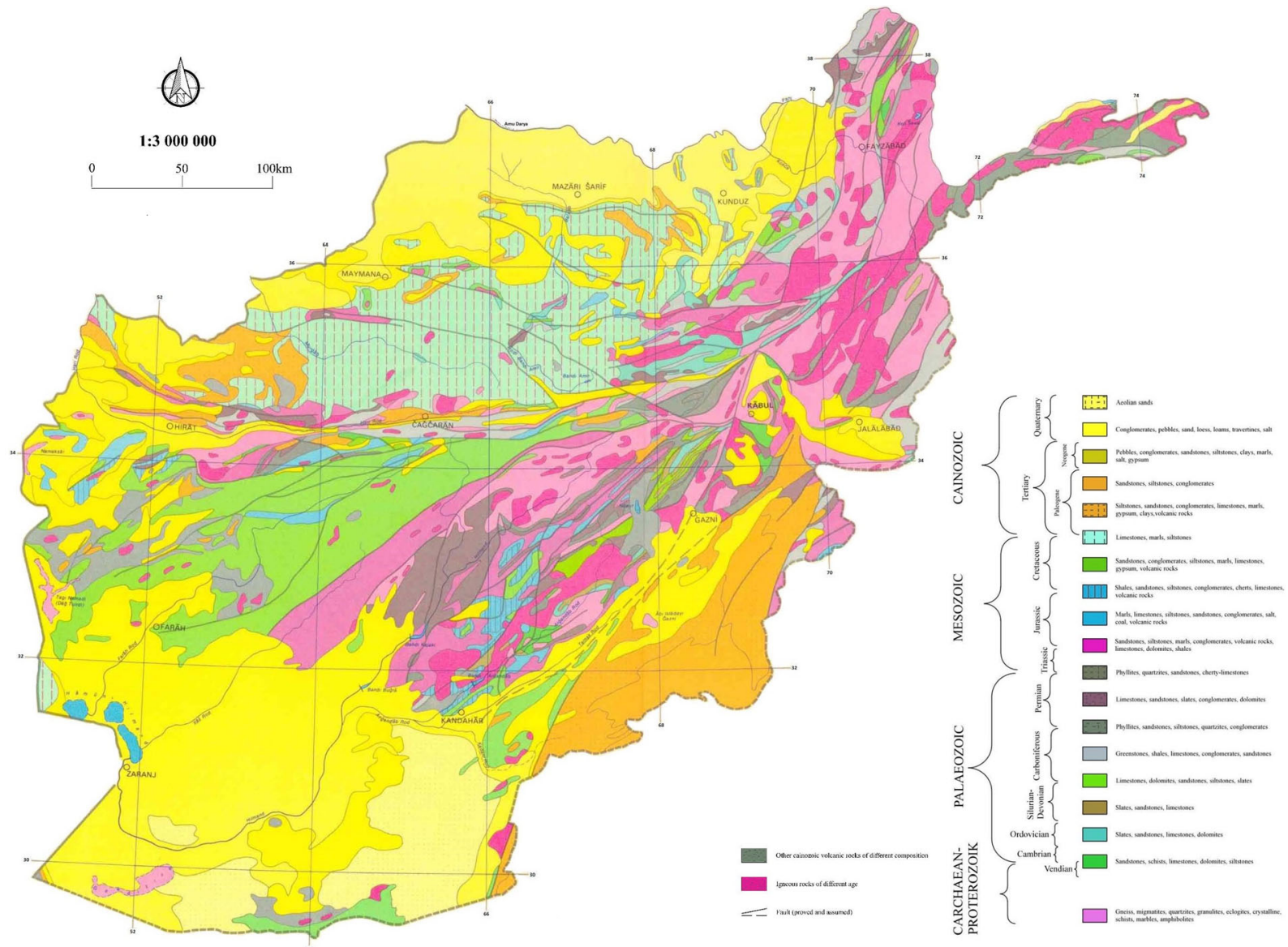

Fig. 2 Geological map of Afghanistan (USGS, 2007)

\section{Water resources of Afghanistan}

Surface water

Afghanistan has different types of rivers; some of them are perennial, in which their main source is the snowmelt. However, some others just flow during rainy seasons and are dry in summer. All the rivers that flow during the year originate from the central mountains such as the Amu Dary, Helmand River, Farah Rud, Kabul River, Arghandab River, Harirud and Murghab River, Kunar River, Panjshir River, Kunduz River, Abi Panj River, and Koccha River. Based on the hydrologic setting, Afghanistan has five river basins shown in Fig. 3: (1) the Amu Darya river basin, (2) the Helmand river basin, (3) the Kabul (Indus) river basin, (4) the Harirud-Morghab river basin, and (5) the Northern river basin (Blind river system). The annual water resources are estimated as 75 billion $\mathrm{m}^{3}$, from which 57 billion $\mathrm{m}^{3}$ are surface and 18 billion $\mathrm{m}^{3}$ are from the groundwater with a total annual water withdrawal of about 20.3 billion $\mathrm{m}^{3}$ in the country (Ahmad and Wasiq, 2004; JICA, 2011; Mahmoodi, 2008; Habib, 2014). However, recent estimates by the Ministry of Energy and Water (MEW, 2016) indicate that the country's annual potential water resources are 77 billion $\mathrm{m}^{3}$, which is a 2 billion $\mathrm{m}^{3}$ difference from the amount reported by the literature.

According to MEW, the available water resources in the basins are as follows: Kabul, 15.183 billion $\mathrm{m}^{3}$, Helmand, 17.136 billion $\mathrm{m}^{3}$, Amu, 18.763 billion $\mathrm{m}^{3}$, Northern, 9.825 billion $\mathrm{m}^{3}$, and Harirud, 16.053 billion $\mathrm{m}^{3}$. The Water Sector Strategy of Afghanistan (2008) reports the surface water availability by basin, where Kabul has 20.76 billion $\mathrm{m}^{3}$, Helmand 9.3 billion $\mathrm{m}^{3}$, Amu 22 billion $\mathrm{m}^{3}$, Northern 1.88 billion $\mathrm{m}^{3}$, and Harirud 3.06 billion $\mathrm{m}^{3}$ of surface water. Itis also important to mention that most of Afghanistan's water is delivered from snowmelt in the Hindu Kush Mountains. There are three major river systems flowing out of the Hindu Kush Mountains in Afghanistan, which are the 


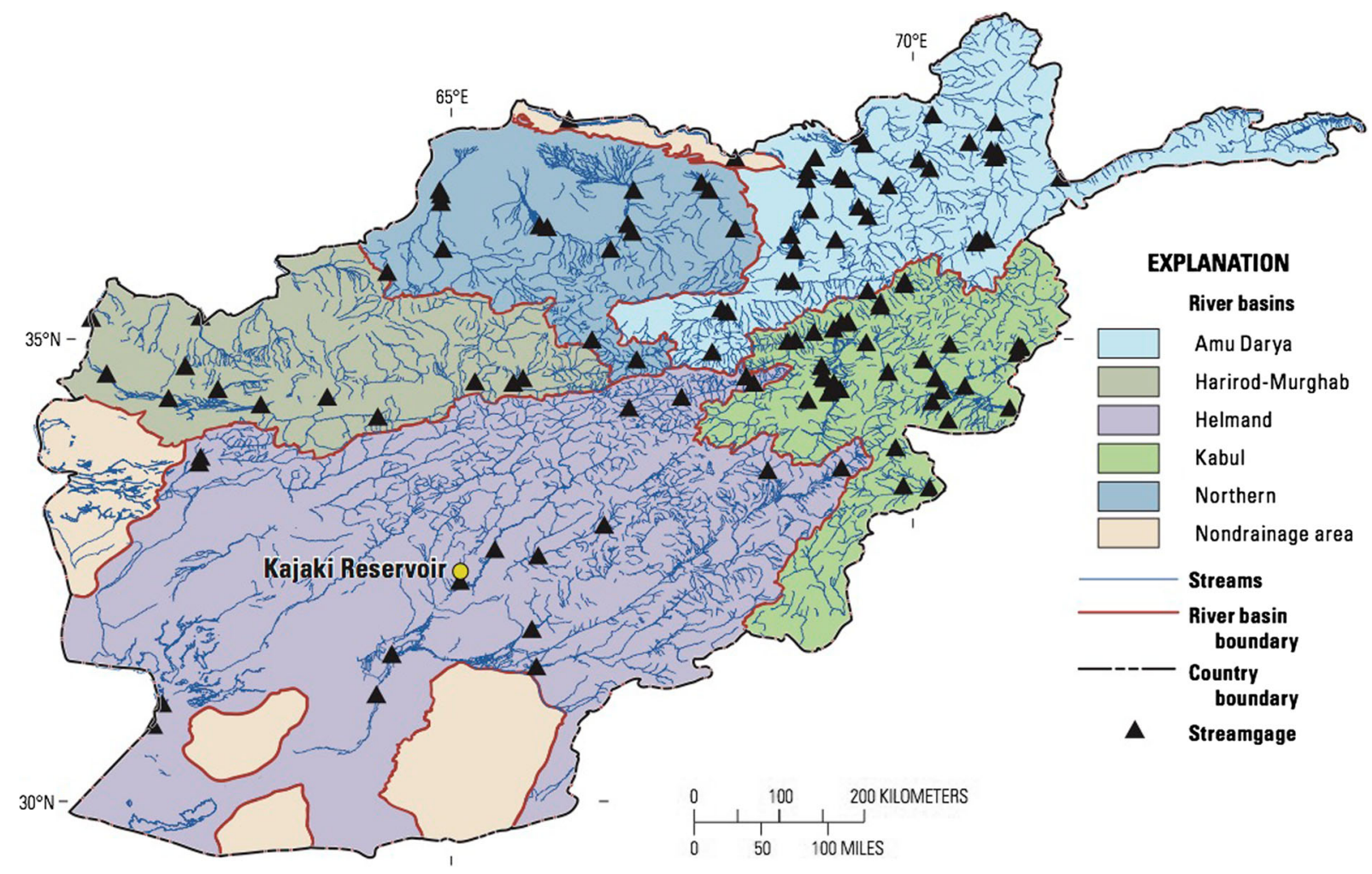

Fig. 3 River basins of Afghanistan (Mack et al. 2014a)

Kabul river system, the Amu Darya system, and the Helmand-Arghandab river system.

There are at least 62 dams in Afghanistan of which, about 20 are large dams (Shroder and Ahmadzai, 2016). Favre and Kamal (2004) mapped a total of 24 dams including existing and proposed ones. Some famous dams in Afghanistan are as follows: Kajaki Dam (Helmand Province), Salma Dam (Heart Province), Dahla Dam (Kandahar Province), Darunta Dam (Nangarhar Province), Mahipar Dam (Kabul Province), Naghlu Dam (Kabul Province), and Sarobi Dam (Kabul Province). These dams have been used for irrigation and hydropower production purposes.

\section{Groundwater}

The natural system of groundwater in Afghanistan involves five hydrogeological units of the upper Cretaceous-Paleocene fracture-karstic aquifers, crystalline rocks, quaternary aquifers, Triassic-lower Cretaceous pressure thermal water, and Neogene aquiferaquitard (Saffi and Kohistani, 2013). The principal aquifer systems include the following: (a) Quaternary deposits in the major river valleys particularly in the Kabul river basin, the river systems in the Helmand river basin to the east (Ghazni, Tarnak, Arghistan, and Arghandab), the Harirud river and certain river systems within Northern flowing rivers and Amu Darya basin; (b) semi-consolidated Neogene age deposits in the Kabul river and other river basins; (c) carbonate rock aquifer systems on the northern flank of the Hindu Kush mountain range and along portions of the Helmand river in Oruzgan Province; and (d) carbonate rock systems at other locations (Uhl, 2003). However, geological properties of the region are very complex while from 1956 to 1963, geological and hydrogeological surveys were conducted in the country and $90 \%$ of the aquifers found were from the Quaternary age. The Kabul Basin aquifers consist of gravel and sand that has a slight cemented property in deeper areas where they can be classified as permeable to very permeable. The largest aquifer is the Logar aquifer which is around $30 \mathrm{~km}^{2}$ with $50 \mathrm{~m}$ average thickness (Tünnermeier and Houben, 2005). According to Mack et al. (2010a), the primary aquifer of the Kabul Basin is highly permeable consisting of sand and gravel with a thickness of less than $80 \mathrm{~m}$ in the 
valleys. They also found that the upper aquifer is underlain by another aquifer comprised of compacted gravel, sand, and clay which is less permeable and around $1000 \mathrm{~m}$ thick. The annual groundwater recharge estimate in the Kabul river basin for the unconsolidated aquifer systems is 520.00 million $\mathrm{m}^{3} /$ year, 2970.00 million $\mathrm{m}^{3}$ /year for Amu Darya basin, 1140.00 million $\mathrm{m}^{3}$ / year for Harirud-Murghab river basin, 2480.00 million $\mathrm{m}^{3} /$ year for Helmand river basin, and 2140.00 million $\mathrm{m}^{3} /$ year for the Northern river basin (Uhl, 2003).

Groundwater is the first and most important resource for drinking water where access to safe drinking water is still limited especially in rural areas of the country as mentioned in the "Introduction" section. Campbell (2015) asserts that $70.9 \%$ of the urban, and $39.4 \%$ of the rural population in Afghanistan has access to safe drinking water, which means that about $46 \%$ of the total population has access to safe drinking water. If we even consider this report as the highest one in terms of access to safe drinking water, there is still a great concern about the quality of water causing different kinds of diseases risking the human health as far as very little is known about its quality because of very limited studies. The Kabul City shallow groundwater is a good example that is unsafe for human health. According to Houben et al. (2009b), insufficient water hygiene can be connected to the high infant mortality rate to some degree. Thus, studies are required to be conducted to investigate groundwater contamination sources in order to prevent further problems that may rise due to groundwater.

Groundwater is also used for irrigation purposes, especially in the areas where there is no access to surface water. Water pumps and turbines are commonly used to withdraw the groundwater for both drinking and irrigation in rural areas; some karez wells (qanats) and springs are also sources for drinking and irrigation water in some areas as it is already mentioned that more than $15 \%$ of the irrigated land receives groundwater. Uhl (2006) claims that even most of the urban areas rely on groundwater for drinking, though more than $95 \%$ of the groundwater usage in the country is still accounted for by irrigation. Due to the drought that occurred between 1999 and 2003, most of the karez wells and springs dried up. A comprehensive study was carried out by Taher et al. (2014) to observe the static and dynamic groundwater levels in 71 wells in the Kabul Basin from 2004 to 2013.

Talking about the groundwater flow, in the Kabul Basin, water basically flows through saturated alluvium and other basin-fill sediments, water might also flow below the alluvium through fractures in the bedrock but that amount is assumed to be less than the flow through the alluvium (Broshears et al., 2005).

\section{Groundwater quality in Afghanistan}

There are few studies carried out in Afghanistan in the last three decades in order to determine groundwater quality of the entire country in detail. The Danish Committee for Aid to Afghan Refugees (DACAAR) is one of the organizations working since 1992 in Afghanistan to supply drinking water to Afghans. DACAAR has undertaken some comprehensive groundwater quality studies and their recent publication by Saffi and Kohistani (2013) is a reliable study about groundwater quality of Afghanistan. The US Geological Survey is another organization that has been working since 2004 to train and support the Afghanistan Geological Survey teams in the Ministry of Mines and Petroleum, as well as scientists in the Ministries of Energy and Water, Agriculture, Irrigation and Livestock, and some other non-governmental organizations in the country to facilitate groundwater investigations (Mack et al., 2014a). Some other studies investigating groundwater quality just concentrate on Kabul Province or Kabul Basin are those by Tünnermeier and Houben (2005), Broshears et al. (2005), Mack et al. (2010a), Sundem (2014), Frahmand (2011), and Mack et al. (2014b). For other provinces, Ansari (2014) assessed physico-chemical characteristics and groundwater quality index in Lashkar Gah City in the Helmand Province, Saffi and Eqrar (2016) investigated groundwater contamination due to arsenic in Maidan Wardak and Ghazni provinces, and Sundem (2014) examined groundwater quality in both Kabul and Maimanah provinces. Still, some other studies have been undertaken by the Government of Afghanistan, UNDP, UNICEF, World Bank, DACAAR, FAO, and the Norwegian Church Aid as cited by Uhl (2003). The Federal Institute for Geosciences and Natural Resources (BGR) is another organization working on groundwater investigations in Afghanistan since 2003 where BGR's groundwater project is funded by the German Federal Republic.

Effects of natural factors on groundwater quality

Contamination results from several pollutants such as arsenic, boron, fluoride, and sulfate in several areas of Afghanistan. The water quality mapping for Afghanistan, of which about $50 \%$ is completed, shows that 
groundwater is plagued by high levels of fluoride and arsenic in some areas. Water quality mapping in the other half of the country cannot be completed due to security concerns currently (UNICEF, 2014). According to Saffi and Kohistani (2013), the provinces of Ghazni, Farah, Panjshir, Laghman, Faryab, Logar, and Ghazni have arsenic contamination in groundwater that exceeds the World Health Organization (WHO) guideline of $10 \mu \mathrm{g} / \mathrm{L}$ of As. Recent research by Saffi and Eqrar (2016) studied 764 drinking water points including hand pump tube wells and dug wells to identify arsenic contamination in groundwater of Ghazni and Maidan Wardak provinces. They found that $61 \%$ of the water samples exceeded the WHO guideline of $10 \mu \mathrm{g} / \mathrm{L}$ of As, and $38 \%$ of the analyzed water samples exceeded the National Drinking Water Quality Standard of Afghanistan (NDWQS) of $50 \mu \mathrm{g} / \mathrm{L}$ of As. Also, out of 42 countries affected by arsenic, Afghanistan is ranked as 22nd with groundwater naturally deteriorated by arsenic; the province of Ghazni had the highest concentration of arsenic in groundwater exceeding the WHO limit (Mukherjee et al., 2006). Moreover, Amini et al. (2008) believe that there is a high probability that Northern Afghanistan's groundwater is contaminated by arsenic though that area is not tested yet and there is no statistical data. However, in the Kabul Basin, two drinking water samples out of 108 exceeded the US Environmental Protection Agency (USEPA) drinking water standard with a highest value of $22.7 \mu \mathrm{g} / \mathrm{L}$ (Broshears et al., 2005), which means that arsenic concentration is not of great concern in some provinces. Still, no complete data exists that can cover the entire country on groundwater contamination due to arsenic. Some significant cases of arsenic concentration in groundwater can be seen in Table 2. The areas where considerable contents of arsenic in the samples from groundwater exist include Ghazni, Laghman, Logar, Herat, and Balkh provinces. Geogenic arsenic occurs in these regions from arsenic minerals embedded in dense clay matrices that promote the mobilization of arsenic into the groundwater. All arsenic-containing minerals, especially sulfides, which are associated frequently with gold ores, copper and iron, are sources of arsenic.

According to the study by Saffi and Kohistani (2013), which was carried out in 19 provinces of Afghanistan for drinking water quality analysis, they found significant fluoride concentrations in north, northeastern, west, and northwestern parts of the country that exceeded the WHO limit of $1.5 \mathrm{mg} / \mathrm{L}$ for drinking water.

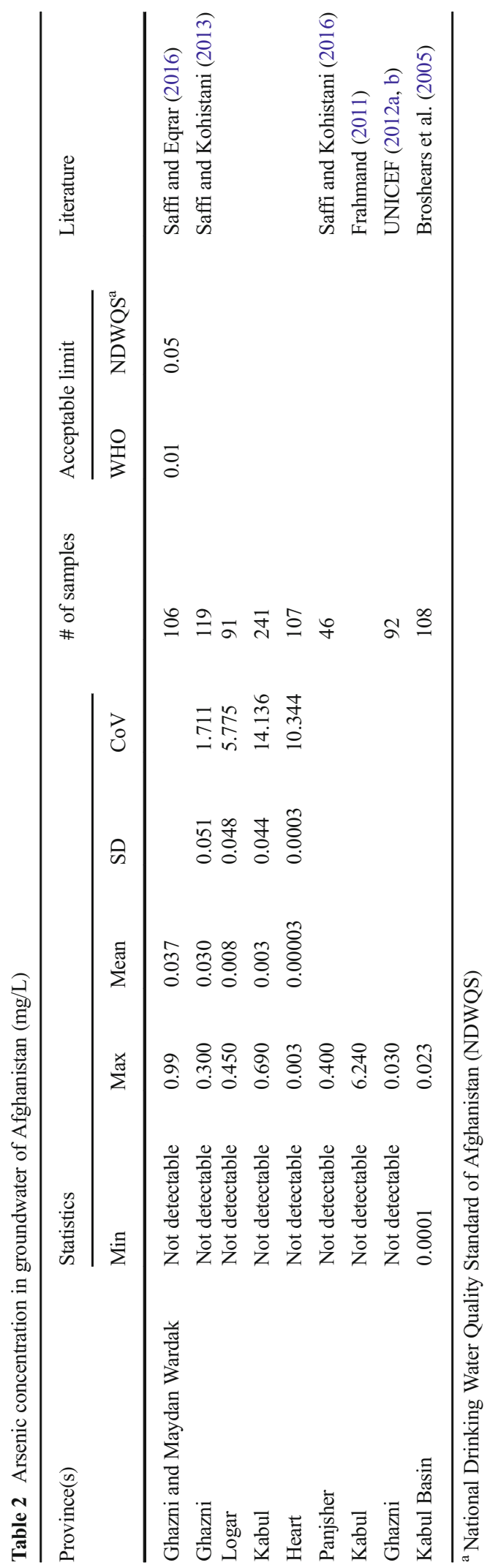


Around $15.9 \%$ of the 1758 analyzed water samples exceeded the WHO's drinking water limit. The highest cases of fluoride concentration observed in groundwater from some provinces are presented in Table 3. The high concentrations of fluoride in groundwater are often found in areas with granite rocks.

In 31 out of 108 samples from groundwater in the Kabul Basin had boron concentration above $1000 \mu \mathrm{g} / \mathrm{L}$, which can be problematic for sensitive plants such as apples and grapes (Broshears et al. 2005). In another study of water samples taken from 19 provinces, 1758 (42\%) water samples from the drinking water points including springs, hand pumped wells, rivers and groundwater monitoring wells had significant Boron concentration that exceeded the WHO limit of $0.5 \mathrm{mg} /$ L (Saffi and Kohistani, 2013). These cases are summarized in Table 4. The element boron usually occurs in groundwater in the form of the anions borate $\left(\mathrm{BO}_{2}\right)$ in this region. $\mathrm{B}$ is present in their acid form (boric acid $\mathrm{H}_{3} \mathrm{BO}_{3}$ ), this acid is not readily dissociate; it remains stable until $\mathrm{pH}>9$ (Hem, 1985).

Suspension of anhydrite and gypsum minerals during their long period of habitation is the cause of high sulfate concentration in the groundwater of north, northeastern, and northwestern Afghanistan, where the range of sulfate concentration varies from $12 \mathrm{mg} / \mathrm{L}$ in Tanfeer Village in Dih Yak District of Ghazni Province to $9000 \mathrm{mg} / \mathrm{L}$ in Ali Abad village in Nahri Shahi District of Balkh Province (Saffi and Kohistani, 2013). The concentration of sulfate in $17 \%$ of the samples analyzed from groundwater in the Kabul Basin is above the WHO's $250 \mathrm{mg} / \mathrm{L}$ limit for drinking water (Tünnermeier and Houben 2005). Table 5 indicates the sulfate concentration in the groundwater resources of Afghanistan. Also, location of high concentration of sulfate, As, B, and F in groundwater resources of Afghanistan is presented in Fig. 4. The results show high concentration of arsenic, boron, fluoride, and sulfate in some provinces that exceed the WHO limit and the National Drinking Water Quality Standard of Afghanistan (NDWQS).

Effects of anthropogenic factors on groundwater quality

Agricultural activities, septic tanks system and domestic-municipal wastes are the most important problems among anthropogenic factors that affect the quality of groundwater in Afghanistan.

Table 3 Fluoride concentration in groundwater of Afghanistan (mg/L)

\begin{tabular}{|c|c|c|c|c|c|c|c|c|c|}
\hline \multirow[t]{2}{*}{ Province(s) } & \multicolumn{5}{|l|}{ Statistics } & \multirow[t]{2}{*}{ \# of samples } & \multicolumn{2}{|c|}{ Acceptable limit } & \multirow[t]{2}{*}{ Literature } \\
\hline & Min & Max & Mean & SD & $\mathrm{CoV}$ & & WHO & NDWQS & \\
\hline Kabul & Not detectable & 5.200 & 0.663 & 0.578 & 0.871 & 276 & 1.5 & 1.5 & Saffi and Kohistani (2013) \\
\hline Heart & 0.200 & 12.800 & 1.796 & 2.199 & 1.225 & 106 & & & \\
\hline Kandahar & 0.010 & 11.030 & 1.159 & 1.777 & 1.533 & 38 & & & \\
\hline Nangarhar & 0.100 & 11.000 & 0.751 & 0.839 & 1.117 & 156 & & & \\
\hline Maydan Wardak & 0.200 & 1.900 & 0.645 & 0.406 & 0.629 & 25 & & & \\
\hline Ghazni & 0.010 & 1.010 & 0.543 & 0.210 & 0.386 & 119 & & & \\
\hline Logar & 0.100 & 1.450 & 0.523 & 0.299 & 0.571 & 91 & & & \\
\hline Faryab & 0.020 & 79.200 & 4.169 & 8.364 & 2.006 & 384 & & & \\
\hline Jawzjan & No data & 55.600 & & & & 2 & & & UNICEF $(2012 a, b)$ \\
\hline Balkh & No data & 40.000 & & & & 30 & & & \\
\hline Faryab & No data & 40.000 & & & & 105 & & & \\
\hline Badghis & No data & 11.000 & & & & 5 & & & \\
\hline Heart & No data & 12.800 & & & & 30 & & & \\
\hline Kandahar & No data & 2.550 & & & & 17 & & & \\
\hline Balkh & 0.020 & 7.450 & 1.820 & 1.554 & 0.854 & 380 & & & Saffi and Kohistani (2014) \\
\hline Kabul Basin & Not detectable & 1.320 & & & & 108 & & & Broshears et al. (2005) \\
\hline Badghis, Balkh, Heart & 0.020 & 63.000 & & & & 76 & & & Saffi (2007) \\
\hline
\end{tabular}


Table 4 Boron concentration in groundwater of Afghanistan (mg/L)

\begin{tabular}{|c|c|c|c|c|c|c|c|c|c|}
\hline \multirow[t]{2}{*}{ Province(s) } & \multicolumn{5}{|l|}{ Statistics } & \multirow[t]{2}{*}{ \# of samples } & \multicolumn{2}{|c|}{ Acceptable limit } & \multirow[t]{2}{*}{ Literature } \\
\hline & Min & Max & Mean & SD & $\mathrm{CoV}$ & & WHO & NDWQS & \\
\hline Kabul & Not detectable & 4.000 & 0.784 & 0.660 & 0.882 & 276 & 2.4 & 2.4 & Saffi and \\
\hline Heart & Not detectable & 3.000 & 0.488 & 0.496 & 1.017 & 106 & & & Kohistani (2013) \\
\hline Kandahar & Not detectable & 0.200 & 0.042 & 0.057 & 1.359 & 38 & & & \\
\hline Nangarhar & Not detectable & 1.800 & 0.192 & 0.305 & 1.588 & 156 & & & \\
\hline Ghazni & Not detectable & 2.900 & 0.513 & 0.481 & 0.938 & 119 & & & \\
\hline Maydan Wardak & 0.100 & 3.200 & 0.641 & 0.709 & 1.106 & 25 & & & \\
\hline Faryab & Not detectable & 24.000 & 1.226 & 2.716 & 2.214 & 384 & & & \\
\hline Farah & Not detectable & 1.650 & 0.125 & 0.286 & 2.284 & 91 & & & \\
\hline Ghor & Not detectable & 6.000 & 0.495 & 1.016 & 2.054 & 37 & & & \\
\hline Badghis & Not detectable & 16.000 & 1.939 & 2.965 & 1.529 & 39 & & & \\
\hline Laghman & Not detectable & 1.120 & 0.311 & 0.297 & 0.957 & 35 & & & \\
\hline Paktya & Not detectable & 0.350 & 0.033 & 0.064 & 1.973 & 67 & & & \\
\hline Kabul Basin & Not detectable & 7.600 & & & & 108 & & & $\begin{array}{l}\text { Broshears et al. } \\
\text { (2005) }\end{array}$ \\
\hline $\begin{array}{l}\text { Badghis, Balkh, Faryab, } \\
\text { Heart, Maydan Wardak }\end{array}$ & 0.050 & 3.900 & & & & 78 & & & Saffi (2007) \\
\hline
\end{tabular}

\section{Agricultural activities}

Agriculture plays an important role in the economic growth of Afghanistan where $50 \%$ of the country's GDP relies on it. Additionally, more than $80 \%$ of the country's population lives in rural areas where the main source of income is based on agriculture and livestock. While it is a vital source of income for Afghans and it is hoped that the country's economy will improve due to the expansion of agriculture, it has some adverse impacts on contamination and pollution of groundwater on the other hand. There is significant amount of excess nitrates that can easily contaminate groundwater from the overuse of chemical fertilizers on farmland. In agricultural areas, nitrates and pesticides in shallow alluvial

Table 5 Sulfate concentration in groundwater of Afghanistan (mg/L)

\begin{tabular}{|c|c|c|c|c|c|c|c|c|c|}
\hline \multirow[t]{2}{*}{ Province(s) } & \multicolumn{5}{|c|}{ Statistics } & \multirow[t]{2}{*}{ \# of samples } & \multicolumn{2}{|c|}{ Acceptable limit } & \multirow[t]{2}{*}{ Literature } \\
\hline & Min & Max & Mean & SD & $\mathrm{CoV}$ & & WHO & NDWQS & \\
\hline Helmand & 178.0 & 496.0 & 336.5 & 130.0 & 0.4 & 4 & 250 & 250 & Ansari (2014) \\
\hline Badghis, Balkh, Faryab, Heart & 1.0 & 2900.0 & & & & 78 & & & Saffi (2007) \\
\hline Kabul & 18.0 & 1360.0 & 120.9 & 150.4 & 1.2 & 276 & & & Saffi and Kohistani (2013) \\
\hline Heart & 48.0 & 2680.0 & 407.8 & 516.2 & 1.3 & 106 & & & \\
\hline Kandahar & 43.0 & 720.0 & 212.1 & 206.8 & 1.0 & 38 & & & \\
\hline Nangarhar & 15.0 & 390.0 & 92.9 & 63.2 & 0.7 & 156 & & & \\
\hline Balkh & 10.0 & 9000.0 & 703.5 & 1370.6 & 2.0 & 55 & & & \\
\hline Ghazni & 12.0 & 450.0 & 57.8 & 50.5 & 0.9 & 119 & & & \\
\hline Farah & 20.0 & 810.0 & 262.0 & 162.0 & 0.6 & 91 & & & \\
\hline Badghis & 87.0 & 2475.0 & 1263.5 & 672.8 & 0.5 & 39 & & & \\
\hline Faryab & 40.0 & 4080.0 & 557.1 & 625.5 & 1.1 & 384 & & & \\
\hline
\end{tabular}




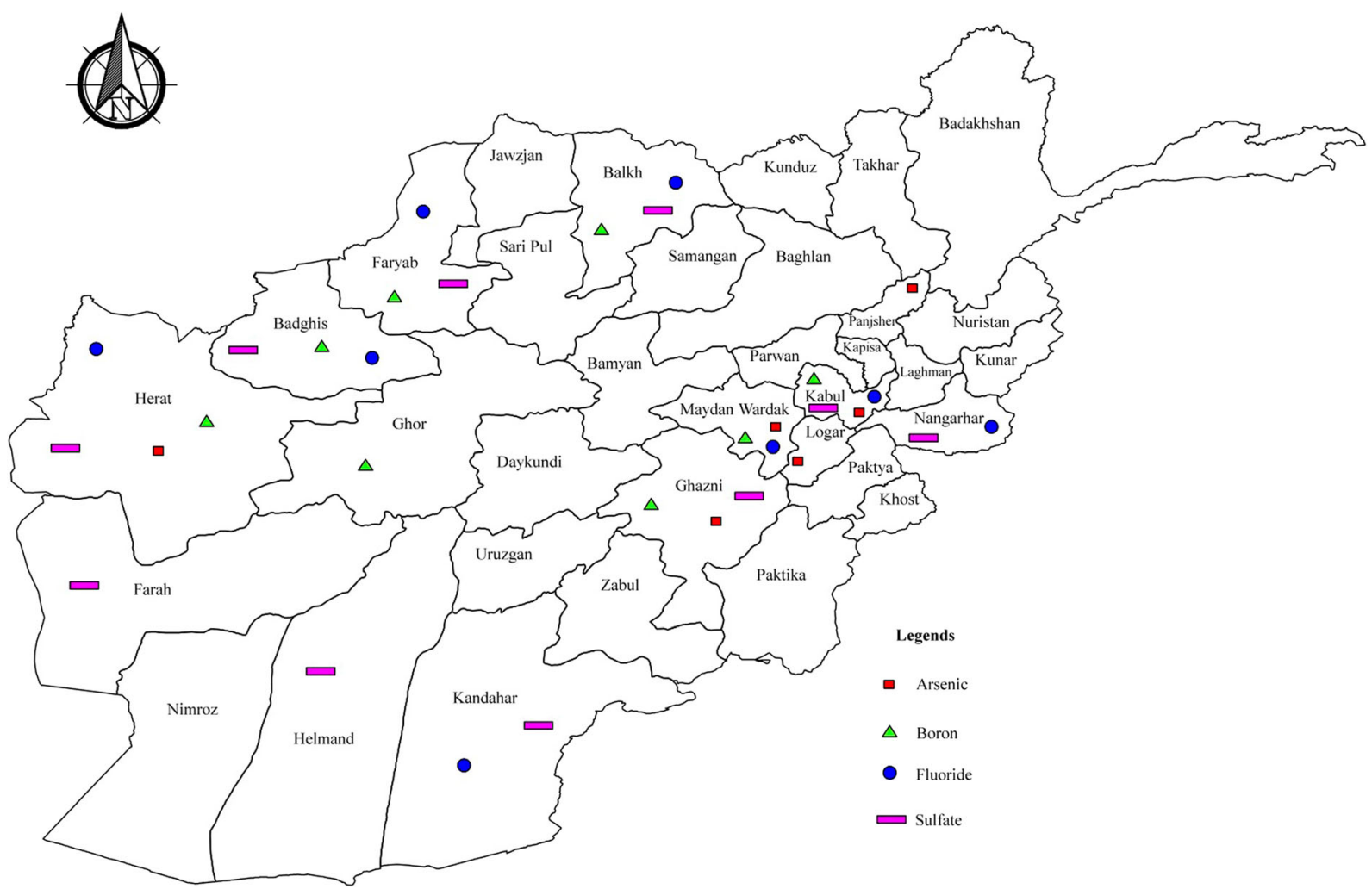

Fig. 4 Groundwater contamination map of Afghanistan due to natural factors

aquifers are the most usual non-point source pollutions noticed due to the widespread application of fertilizers (Bartzas et al. 2015; Böhlke 2002; and Kim et al. 2009; Zhou 2015). Animal waste that contains nitrate is also a considerable factor for groundwater contamination in areas with livestock. Frequently nitrate concentrations in agricultural areas are linked with microbial and pesticide contaminations (Mahvi et al. 2005). Still, nitrate contamination in groundwater is a common problem in many parts of the world due to many causes, e.g., intensive agriculture, untreated sanitation in densely populated areas, or from non-point sources such as irrigation of land by sewage effluents. Nevertheless, the heavy use of nitrogenous fertilizers in crop systems is the largest contributor to anthropogenic nitrogen in groundwater worldwide (Suthar et al., 2009). Some of the major concerns about nitrate $\left(\mathrm{NO}_{3}{ }^{-}\right)$contamination/ loading in both groundwater and surface water systems include health risks to humans through drinking water (i.e., methemoglobinemia and potential carcinogenic effects) and degradation of the local ecosystems (i.e., excessive plant and algal growth) (Murgulet and Tick, 2009). Numerous studies report that the use of rural land, especially agricultural practices, can cause nitrate contamination of underlying groundwater (Bouwer, 1978; Driscoll, 1986; and Vowinkel and Tapper 1995). Thus, agricultural activities are one of the noticeable anthropogenic factors contaminating groundwater in the country. Poor quality of water is not just harmful for human health, but it will affect the productivity and quality of agricultural crops as well. Azizullah et al. (2011) confirm that use of poor quality water for irrigation will lower productivity of crops. Since more than $50 \%$ of the irrigation water is wasted due to the traditional and weak irrigation practices in Afghanistan, the risk of groundwater contamination due to runoff of extra water contaminated with nitrates and pesticides is high. Still, there is no a specific strategy or guidance in the country to be followed in order to prevent this type of groundwater contamination. The nitrate concentration in the groundwater is studied by Saffi and Kohistani (2013) with some remarkable figures in several provinces as shown in Table 6. In another study, Zhou (2015) observed considerable nitrate concentration in about 700 well points data with majority in Asia, especially in Afghanistan where nitrate was 
Table 6 Nitrate concentration in groundwater of Afghanistan (mg/L)

\begin{tabular}{|c|c|c|c|c|c|c|c|c|c|}
\hline \multirow[t]{2}{*}{ Province(s) } & \multicolumn{5}{|l|}{ Statistics } & \multirow[t]{2}{*}{ \# of samples } & \multicolumn{2}{|c|}{ Acceptable limit } & \multirow[t]{2}{*}{ Literature } \\
\hline & Min & Max & Mean & SD & $\mathrm{CoV}$ & & WHO & NDWQS & \\
\hline Helmand & 22.30 & 62.00 & 39.52 & 17.27 & 0.44 & 4 & 50 & 50 & Ansari (2014) \\
\hline Kabul & Not detectable & 128.00 & & & & & & & Frahmand (2011) \\
\hline Kabul Basin & 0.60 & 40.20 & 6.20 & & & 43.00 & & & Mack et al. (2010b) \\
\hline Nangarhar and Ghor & 0.08 & 90.00 & & & & 76 & & & Saffi (2007) \\
\hline Kabul & 0.10 & 96.00 & 24.06 & 24.80 & 1.03 & 276 & & & Saffi and Kohistani (2013) \\
\hline Heart & 0.01 & 77.00 & 13.66 & 18.57 & 1.36 & 106 & & & \\
\hline Kandahar & 1.40 & 52.90 & 7.11 & 8.05 & 1.13 & 38 & & & \\
\hline Ghazni & 0.44 & 80.00 & 18.82 & 20.36 & 1.08 & 119 & & & \\
\hline Ghor & 0.58 & 57.00 & 14.18 & 17.24 & 1.21 & 37 & & & \\
\hline Faryab & Not detectable & 88.00 & 7.77 & 14.61 & 1.88 & 384 & & & \\
\hline
\end{tabular}

measured from year 1990 to 2013. The results of this study showed that concentration of nitrate exceeded $100 \mathrm{mg} / \mathrm{L}$ in groundwater in Afghanistan. Locations of high concentrations of nitrate, Escherichia coli, and fecal coliforms in some provinces are presented in Fig. 5.

\section{Septic tanks system}

In Afghanistan, most of the cities and towns do not have central sewer line systems; there are just individual septic tanks installed for each house. These tanks are not constructed in a proper way to prevent infiltration of

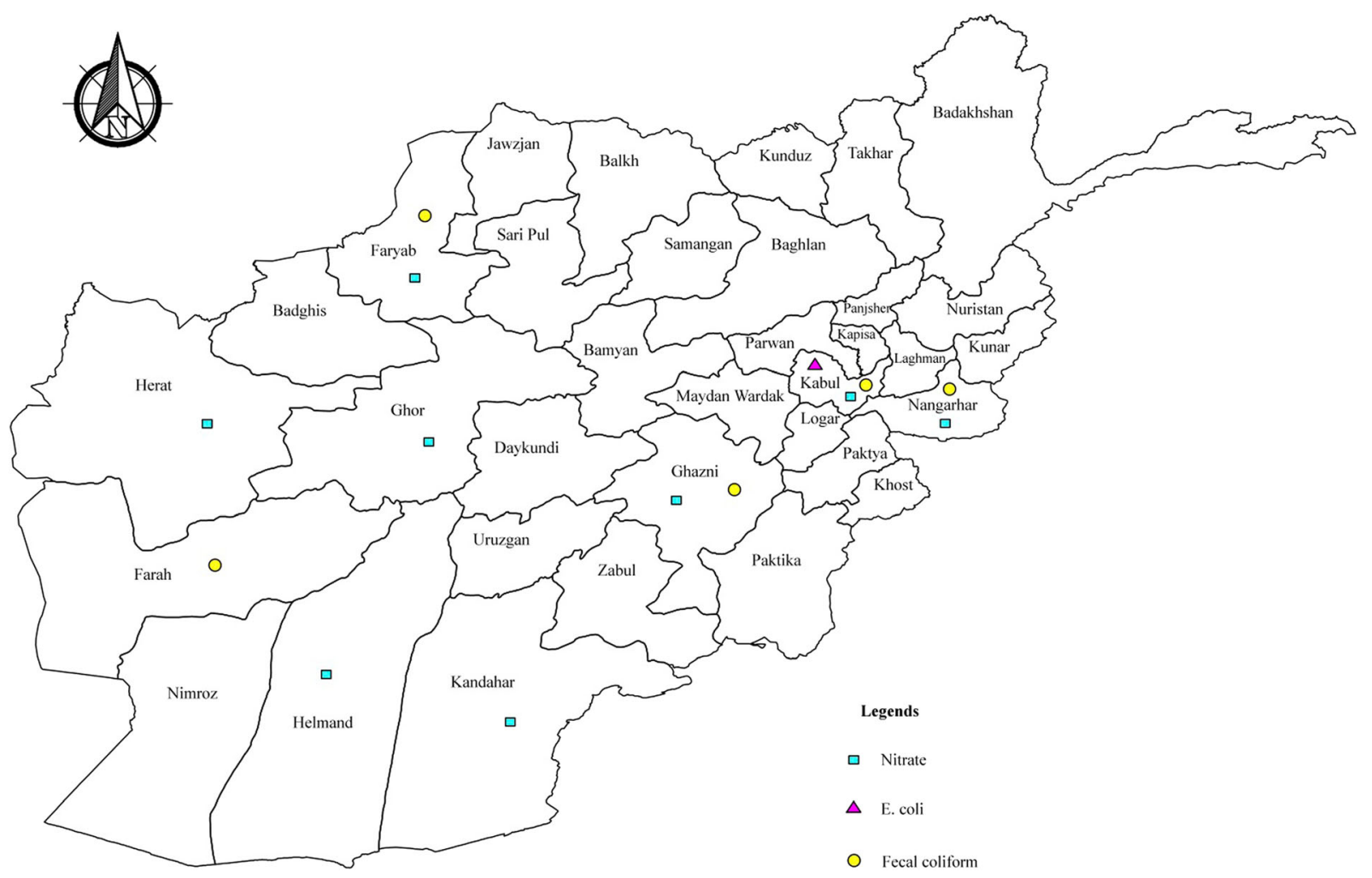

Fig. 5 Groundwater contamination map of Afghanistan due to anthropogenic factors 
wastewater into the groundwater. In Kabul City, one third of the wastewater infiltrates into groundwater due to the absence of a wastewater disposal network (Houben et al. 2009a). Subsurface sewage disposal systems are the largest sources of groundwater contamination (Miller, 1980). The wastewater and human excreta obviously carries bacteria, viruses, E. coli, and nitrates that are dangerous to health, especially for children. Nitrate is a very important factor for drinking water hygiene because above $50 \mathrm{mg} / \mathrm{L}$ concentration of nitrate from the WHO limit can adversely affect human health especially children health. Ansari (2014) found nitrate concentration of $132.4 \mathrm{mg} / \mathrm{L}$ in a shallow well groundwater sample in Lashkar Gah City in the Helmand Province where the main cause of groundwater contamination was wastewater infiltration from the nearby septic tanks that were constructed improperly or without engineering. The $132.4 \mathrm{mg} / \mathrm{L}$ nitrate concentration exceeds the $50 \mathrm{mg} / \mathrm{L}$ guideline value of the WHO. With the expansion of cities and construction of new houses, the number of these inappropriate septic tanks is increasing day by day, which will cause a serious problem for groundwater quality in the country in the future. Ansari (2014) further claims that sanitation in Lashkar Gah City is at a very low level with no facilities for wastewater or solid waste treatment. Broshears et al. (2005) measured the nitrate concentration in 108 wells in the urban area of Kabul river basin, groundwater in 14 wells exceeded the USEPA drinking water standard of $10 \mathrm{mg} / \mathrm{L} \mathrm{N}$. In this research, E. coli was noted in 24 samples out of 108 , which is a clear indication of fecal contamination. In a study carried out by Houben et al. (2009b) on Kabul City groundwater quality, they found that in water samples from 290 shallow and deep wells, $42 \%$ of the samples exceeded the WHO limit. In another study conducted by the Afghanistan Geological Survey (AGS), they collected water samples from 92 groundwater, karez, spring, and 8 surface water sites for quality determinations, while bacterial contamination such as $E$. coli and total coliform were detected in both groundwater and surface water that exceeded the standards for international drinking water (Mack et al., 2010b). Hence, there are different kinds of waterborne diseases in the country such as diarrhea, cholera, and dysentery (Ansari, 2014; Saffi and Kohistani, 2013; and Habib, 2014) because of the poor septic tanks system that causes the drinking groundwater quality contaminated. Tables 7 and 8 indicate particular significant contamination of groundwater due to fecal coliforms and $E$. coli in some provinces of Afghanistan.

\section{Domestic and municipal wastes}

Landfills for waste are one of the foremost threats to groundwater resources (Fatta et al., 1999) not only in Afghanistan but throughout the world (US EPA, 1984). The solid waste placed in landfills or open dumps is subject to either groundwater underflow or infiltration from precipitation or any other possible infiltration of water (Nagarajan et al., 2012). Domestic wastes are also one of the significant anthropogenic factors in the groundwater contamination process in Afghanistan. As per Houben et al. (2009b), because of weak waste disposal and sewage treatment systems, shallow groundwater in the Kabul City is extremely polluted. Lashkaripour and Hussaini (2008) report that groundwater in the Kabul Basin is substantially affected by sewage in the neighborhood of urban areas. Mack et al. (2010a) also confirm that the contamination of groundwater by human activities in central Kabul subbasin is due to the absence of waste and wastewater treatment facilities and contains concentrations of boron, nitrate, and chloride. Uhl (2006) insisted that the weak drainage and wastewater disposal practices

Table 7 Fecal coliforms concentration in groundwater of Afghanistan $(\mathrm{Col} / 100 \mathrm{ml})$

\begin{tabular}{llllllll}
\hline Province(s) & Statistics & \multicolumn{7}{c}{} & & \# of samples & Literature \\
\cline { 2 - 6 } & Min & Max & Mean & SD & CoV & & Saffi and Kohistani (2013) \\
\hline Kabul & Not detectable & 820.00 & 12.32 & 64.69 & 5.25 & 276 & 119 \\
Ghazni & Not detectable & 377.00 & 13.43 & 49.47 & 3.68 & 384 & \\
Faryab & Not detectable & 255.00 & 8.28 & 22.34 & 2.70 & \\
Nangarhar & Not detectable & 300.00 & 15.58 & 45.69 & 2.93 & 170 & \\
Farah & Not detectable & 291.00 & 25.65 & 64.86 & 2.53 & 91 & \\
\hline
\end{tabular}


Table 8 E. coli concentration in groundwater of Afghanistan $(\mathrm{Col} / 100 \mathrm{ml})$

\begin{tabular}{lllllll}
\hline Province(s) & Statistics & & & & \# of samples & Literature \\
\cline { 2 - 6 } & Min & Max & Mean & SD & CoV & \\
\hline Kabul & Not detectable & $>200$ & & 108 & Broshears et al. (2005) \\
Kabul & Not detectable & 40.00 & & & Frahmand (2011) \\
Kabul Basin & Not detectable & 461.00 & 29.00 & & Mack et al. (2010b) \\
\hline
\end{tabular}

have caused water quality deterioration in urban areas of Afghanistan. Ansari (2014) also claims that the absence of solid waste treatment systems in Afghanistan have caused a potential for groundwater contamination. He further argues that the dumping of solid wastes from Lashkar Gah City in Helmand Province in rivers or sites outside the city is an important anthropogenic factor that may cause groundwater pollution. These examples show that the Environmental Protection Agency of Afghanistan is still not able to overcome these problems and may not be able to do it in the near future.

\section{Groundwater quality concerns in the country}

Quality of groundwater is a concern for both human health and the environment in Afghanistan. For example, the population exposed to elevated arsenic in drinking water in the Ghazni and Logar areas is estimated at 500,000.00 (Murcott, 2012). One study was conducted where in three mining regions, and the villagers located in the mountainous areas were seriously exposed to arsenic in the drinking water around Ghazni region (Ravenscroft et al., 2009). The source of arsenic was presumed to be oxidation of arsenopyrite associated with copper mineralization.

A majority of the Afghan population suffers the problem of adequate and safe supplies of water because of contamination from a wide variety of sources such as lack of water resource management regulations and lack of the river basin infrastructure, compounded by a recent 5-year drought and seasonal flooding (Williams-Sether, 2008). Estimates show that 191 out of 1000 children die before their 5 th birthday, of which 44 die because of unsafe water and poor sanitation as cited by Saffi and Kohistani (2013). Some major concerns were reported by Saffi and Kohistani (2013) regarding groundwater quality and quantity with quantitative groundwater concerns of (1) continuing water logging, (2) imbalance in streams/river and aquifer interaction, (3) continuing lowering of the groundwater table, (4) drying of most of the karez, large diameter wells and springs, (5) excessive discharge trends and deteriorating water quality, and (6) depletion of groundwater natural storage. Qualitative groundwater concerns are (1) arsenic contamination, (2) boron contamination, (3) salinity contamination, (4) fecal coliform bacteria, (5) nitrate contamination, (6) fluoride contamination, (7) chromium contamination, (8) hardness, and (9) sodium and chloride contamination. The study covers 19 out of 34 provinces in Afghanistan and can be counted as countrywide study as there is no other data that can cover the entire country. In the Kabul river basin, water samples were taken from 108 wells during July and November 2004, which showed that 13 wells exceeded the USEPA drinking water standards for nitrate, with 44 wells with excessive boron, 22 wells with excessive bromide, 54 wells with excessive dissolved solids, 14 wells with excessive sulfate, 11 wells with excessive chloride, and 73 wells with excessive fecal coliform bacteria contamination (Thomas and Eqrar, 2011). Moreover, Shroder and Ahmadzai (2016) claim that Afghanistan is one of the worst countries in South and Central Asia in terms of access to improved and healthy water supplies. Thus, these concerns should be taken into account to ensure a countrywide investigation on groundwater quality data collection, analysis, and results in order to establish some preventive regulations linked to anthropogenic contamination of groundwater. Even though the Environmental and Water Laws of Afghanistan emphasize the protection of water resources, these laws are not fully enforced in the country due to the weak law enforcement in the country at the moment. Article number 38 of the Environmental Law "Preventing and Remedying Effects of Pollution of Water Resources" says that an owner of land, a person in control of land or a person who occupies or uses the land on which any activity or process is performed or undertaken which 
causes or is likely to cause significant pollution of a water resource, must take the following measures to prevent any such pollution from occurring:

- Cease, modify, or control any action or process causing the pollution

- Comply with any prescribed waste standard or pollution management practice

- Contain or prevent the movement of pollutants

- Eliminate any source of the pollution

- Remedy the effects of the pollution

- Remedy the effects of any disturbance to the bed and banks of a watercourse

Furthermore, the Water Law Article number 30 "Non-Contamination of Water Resources" states that

- Real and legal persons cannot contaminate water resources by using or discharging garbage, wastewater, industrial waste, chemicals, and toxics beyond the limit

- A violator, based on this law, is required to compensate for losses and shall be punished depending on the circumstances

However, none of these rules are enforced and applied practically in the field yet. In addition, most people are not aware of such laws or do not understand and cannot even read these laws in rural areas, which accounts for $80 \%$ of the Afghan population because of the illiteracy. Thus, much effort is required to ensure Afghan society can fully understand the importance of such a precious resource, which is under risk of deterioration.

In June 2015, a National Groundwater Conference was held with cooperation of related Afghan ministries and non-governmental organizations (NGOs) involved and supporting groundwater investigation projects in Afghanistan. This was the first conference on a national level that addressed concerns about groundwater problems in Afghanistan and offered solutions for the comprehensive study of groundwater of the entire country. This conference announced their final declaration emphasizing groundwater coordination between the responsible ministries, establishment of an information management system for effective communication and sharing of data among the stakeholders for any development associated with groundwater, mapping of groundwater resources for the whole country, determination of support and funding needed from donors working in Afghanistan, enforcement of law, and preparation of an action plan for the next 5 years. The key ministries attending the conference were the Ministry of Energy and Water (MEW), Ministry of Mines and Petroleum (MMP), Ministry of Agriculture, Irrigation and Livestock (MAIL), Ministry of Urban Development of Afghanistan (MUDA), and Ministry of Rural Rehabilitation and Development (MRRD). Therefore, there is hope that some detailed information about Afghanistan's groundwater will be available in the future based on the decisions that were made at this conference. Yet, there are many challenges ahead for these countrywide studies where security is the first and the main challenge.

\section{Conclusions and recommendations}

Groundwater is the main source of drinking water in Afghanistan where no detailed countrywide studies are available about quality yet. Usually, groundwater is deteriorated naturally or via human activities. Natural significant factors that affect the quality of groundwater in Afghanistan are arsenic, boron, fluoride, and sulfate based on the existing literature, which are concerns for human health and even agriculture. Among the anthropogenic factors that can affect groundwater quality adversely are agricultural activities, septic tanks system, and domestic and municipal wastes. Still, little or no information is available for the groundwater quality of the whole country. Also, the government has not enforced the regulations in place to prevent further groundwater contamination, particularly due to anthropogenic factors. Since very little attention has been paid toward groundwater deterioration in the country, there will be a serious risk to groundwater quality in the next 10-20 years due to the population increase, huge mining activities (just begun), increased industrial activities, and with the expansion of agriculture. Therefore, government and involved institutions should take necessary actions to prevent further groundwater contaminations that may reduce problems associated with groundwater especially considering health issues.

The major factors threatening the groundwater resources are domestic and industrial wastes, septic tanks that are rapidly increasing in the cities, and agricultural activities that need to be managed. The wastewater from latrines and septic tanks infiltrating into groundwater 
which contaminates the water in the cities and may cause a large health problem for drinking water in the future. Therefore, it is very important to monitor groundwater resources continuously. Study of water resources, especially groundwater resources is one of the fields that require very good and effective knowledge in both theory and practice. In addition to expertise, investigation of groundwater will need sufficient funding, equipment, time, and obviously security, which is the biggest challenge at the moment. Finally, taking all concerns into account, further studies should show much bigger picture of the case so that to understand the problem in details.

\section{References}

Ahmad, M., and Wasiq, M. (2004). Water resources development in Northern Afghanistan and its implications for Amu Darya Basin (No. 36). World Bank Publications.

Amini, M., Abbaspour, K. C., Berg, M., Winkel, L., Hug, S. J., Hoehn, E., Yang, H., \& Johnson, C. A. (2008). Statistical modeling of global geogenic arsenic contamination in groundwater. Environmental Science \& Technology, 42(10), 3669-3675.

ANDS. (2008). Water sector strategy for Afghanistan. Afghanistan National Development Strategy. Kabul, Afghanistan.

Ansari, A. (2014). A study on domestic water consumption, assessment of physico-chemical characteristics and water quality index of ground and surface water samples of Lashkargah City, Helmand Province, Afghanistan. Master thesis, Faculty of Engineering and Build Environment, Universiti Kebangsaan, Malaysia.

Azizullah, A., Khattak, M. N. K., Richter, P., \& Häder, D. P. (2011). Water pollution in Pakistan and its impact on public health-a review. Environment International, 37(2), 479497.

Bartzas, G., Tinivella, F., Medini, L., Zaharaki, D., \& Komnitsas, K. (2015). Assessment of groundwater contamination risk in an agricultural area in north Italy. Information Processing in Agriculture, 2(2), 109-129.

Bouwer, H. (1978). Groundwater hydrology. New York: McGrawHill.

Böhlke, J. K. (2002). Groundwater recharge and agricultural contamination. Hydrogeology Journal, 10(1), 153-179.

Broshears, R. E., Akbari, M. A., Chornack, M. P., Mueller, D. K., and Ruddy, B. C. (2005). Inventory of ground-water resources in the Kabul Basin, Afghanistan: U.S. Geological Survey Scientific Investigations Report 2005-5090, 34 p., http://pubs.usgs.gov/sir/2005/5090/.

Campbell, J. (2015). A dry and ravaged land: investigating water resources in Afghanistan. Earth mag, 60(1-2), 48-55.

Driscoll, F. G. (1986). Groundwater and wells. St. Paul: Johnson Publishing Division.

Fatta, D., Papadopoulos, A., \& Loizidou, M. (1999). A study on the landfill leachate and its impact on the groundwater quality of the greater area. Environmental Geochemistry and Health, 21(2), 175-190.

Favre, R., and Kamal, G. M. (2004). Watershed atlas of Afghanistan: Kabul, Afghanistan, Afghanistan Information Management Service, 183 p., http://aizon.org/watershed_ atlas.htm.

Frahmand, A. S. (2011). GIS based ground water quality analysis in Kabul City region. Geospatial World Forum. Hyderabad, India.

Habib, H. (2014). Water related problems in Afghanistan. International Journal of Educational Studies, 1(3), 137-144.

Hem, J.D. (1985). Study and interpretation of the chemical characteristics of natural water. US Geol. Surv. Water Supp. Pap. 2254, third ed.

Houben, G., Niard, N., Tünnermeier, T., \& Himmelsbach, T. (2009a). Hydrogeology of the Kabul Basin (Afghanistan), part I: aquifers and hydrology. Hydrogeology Journal, 17(3), 665-677.

Houben, G., Tünnermeier, T., Eqrar, N., \& Himmelsbach, T. (2009b). Hydrogeology of the Kabul Basin (Afghanistan), part II: groundwater geochemistry. Hydrogeology Journal, 17(4), 935-948.

JICA. (2011). Needs assessment survey for water resources management and development in Afghanistan. Japan International Cooperation Agency, Final Report.

Kim, K. H., Yun, S. T., Choi, B. Y., Chae, G. T., Joo, Y., Kim, K., \& Kim, H. S. (2009). Hydrochemical and multivariate statistical interpretations of spatial controls of nitrate concentrations in a shallow alluvial aquifer around oxbow lakes (Osong area, central Korea). Journal of Contaminant Hydrology, 107(3), 114-127.

Lashkaripour, G. R., \& Hussaini, S. A. (2008). Water resource management in Kabul river basin, eastern Afghanistan. The Environmentalist, 28(3), 253-260.

Mack, T. J., Chornack, M. P., Coplen, T. B., Plummer L. N., Rezai, M. T., and Verstraeten, I. M. (2010a). Availability of water in the Kabul Basin, Afghanistan: U.S. Geological Survey Fact Sheet 2010-3037, 4 p., http://pubs.usgs.gov/fs/2010/3037/.

Mack, T. J., Akbari, M. A., Ashoor, M. H., Chornack, M. P., Coplen, T. B., Emerson, D. G., Hubbard, B. E., Litke, D. W., Michel, R. L., Plum-mer, L. N., Rezai, M. T., Senay, G. B., Verdin, J. P., and Verstraeten, I. M. (2010b). Conceptual model of water resources in the Kabul Basin, Afghanistan: U.S. Geological Survey Scientific Investigations Report 2009-5262, 240 p., http://pubs.usgs.gov/sir/2009/5262/.

Mack, T. J., Chornack, M. P., Vining, K. C., Amer, S. A., Zaheer, M. F., \& Medlin, J. H. (2014a). Water resources activities of the US Geological Survey in Afghanistan from 2004 through 2014. USGS Fact Sheet, 2014-3068 No. 265.

Mack, T. J., Chornack, M. P., Flanagan, S. F., and Chalmers, A. T. (2014b). Hydrogeology and water quality of the Chakari Basin, Afghanistan, U.S. Geological Survey Scientific Investigation Report 2014-5113, 35 p., http://dx.doi. org/10.3133/sir20145113.

Mahmoodi, S. M. (2008). Integrated water resources management for rural development and environmental protection in Afghanistan. Journal of Developments in Sustainable Agriculture, 3(1), 9-19.

Mahvi, A. H., Nouri, J., Babaei, A. A., \& Nabizadeh, R. (2005). Agricultural activities impact on groundwater nitrate 
pollution. International Journal of Environmental Science \& Technology, 2(1), 41-47.

Miller, D.W. (1980). Waste-disposal effects on ground water: BerkIey, Calif., Premier Press, 512 p.

Ministry of Energy and Water (MEW). (2016). National water master plan and river basin master plans. Strategic planning framework for water sector development. A presentation (not in publication). Herat, Afghanistan.

Mukherjee, A., Sengupta, M. K., Hossain, M. A., Ahamed, S., Das, B., Nayak, B., Lodh, D., Rahman, M. M., and Chakraborti, D. (2006). Arsenic contamination in groundwater: a global perspective with emphasis on the Asian scenario. Journal of Health, Population and Nutrition, 142-163.

Murcott, S. (2012). Arsenic contamination in the world, an international sourcebook. London: IWA Publishing.

Murgulet, D., \& Tick, G. R. (2009). Assessing the extent and sources of nitrate contamination in the aquifer system of southern Baldwin County, Alabama. Environmental Geology, 58(5), 1051-1065.

Nagarajan, R., Thirumalaisamy, S., and Lakshumanan, E. (2012). Impact of leachate on groundwater pollution due to nonengineered municipal solid waste landfill sites of erode city, Tamil Nadu, India. Iranian Journal of Environmental Health Science \& Engineering. Volume 9, Number 1, Page 1.

Qureshi, A. S. (2002). Water resources management in Afghanistan: the issues and options (Vol. 49). IWMI.

Ravenscroft, P., Brammer, H., \& Richards, K. (2009). Arsenic pollution: A global synthesis. Chichester: John Wiley \& Sons Ltd.

Saffi, M. H. (2007). Groundwater resources at risk in Afghanistan. Danish Committee for Aid to Afghan Refugees, Scientific Investigation Report. Kabul, Afghanistan.

Saffi, M. H. and Eqrar, M. N. (2016). Arsenic contamination of groundwater in Ghazni and Maidan Wardak provinces, Afghanistan. Arsenic Research and Global Sustainability: Proceedings of the Sixth International Congress on Arsenic in the Environment (As2016), June 19-23, 2016, Stockholm, Sweden. CRC Press, 41-42.

Saffi, M. H., \& Kohistani, A. J. (2013). Water resources potential, quality problems, challenges and solutions in Afghanistan. Danish Committee for Aid to Afghan Refugees. Kabul: Scientific Investigation Report.

Saffi, M. H., and Kohistani, A. J. (2014). Study on water quality status with respect to Fluoride contamination in the drinking water sources Balkh Province, Afghanistan. Danish Committee for Aid to Afghan Refugees, Scientific Investigation Report. Kabul, Afghanistan.

Saffi, M. H., and Kohistani, A. J. (2016). Arsenic Contamination of Groundwater in Panjsher Province Afghanistan. Danish Committee for Aid to Afghan Refugees, Scientific Investigation Report. Kabul, Afghanistan.

Shroder, J. F., and Ahmadzai, S. J. (2016). Transboundary water resources in Afghanistan: Climate change and land-use implications. Elsevier Inc.

Sundem, L. (2014). Quality of drinking water in Afghanistan. Master thesis. Norwegian University of Life Sciences, Faculty of Environmental Sciences and Technology, Department of Environmental Sciences.

Suthar, S., Bishnoi, P., Singh, S., Mutiyar, P. K., Nema, A. K., \& Patil, N. S. (2009). Nitrate contamination in groundwater of some rural areas of Rajasthan, India. Journal of Hazardous Materials, 171(1), 189-199.

Taher, M. R., Chornack, M. P., and Mack, T. J. (2014). Groundwater levels in the Kabul Basin, Afghanistan, 2004 2013: U.S. Geological Survey Open-File Report 2013-1296, 51 p., http://dx.doi.org/10.3133/ofr20131296.

Thomas, V., and Eqrar, N. (2011). Managing water resources, scarcity, and climate shocks. Afghanistan Human Development Report Chapter 2. Centre for Policy and Human Development, Kabul, Afghanistan.

Tünnermeier, T., \& Houben, G. (2005). Hydrogeology of the Kabul Basin, part I: geology, aquifer characteristics, climate and hydrography. Foreign Office of the Federal Republic of Germany, AA-Gz'GF07, 885(3), 16.

Uhl V. W. (2003). Afghanistan: an overview of groundwater resources and challenges. Rana Associates, Inc. Washington Crossing, PA, USA.

Uhl, V. W. (2006). Afghanistan: an overview of groundwater resources and challenges. Groundwater, 44(5), 626-627.

UNICEF. (2014). Children and women in Afghanistan: a situation analysis. United Nations Children's Fund. Kabul, Afghanistan.

UNICEF. (2012a). Arsenic contamination of drinking water in Afghanistan. WASH Section. https://www. humanitarianresponse.info/sites/www.humanitarianresponse. info/files/WASH_WQ_ARSENIC_NATIONAL.pdf (Accessed February 17, 2017).

UNICEF. (2012b). Fluoride contamination of drinking water in Afghanistan. WASH Section. https://Www. humanitarianresponse.info/sites/www.humanitarianresponse. info/files/WASH_WQ_FLUORIDE_NATIONAL.pdf (Accessed February 17, 2017).

United States Environmental Protection Agency (US EPA). (1984). A ground water protection strategy for the Environmental Protection Agency. Office of Drinking Water.

United States Geological Survey (USGS). (2007). Geological map of Afghanistan, https:/gcmd.nasa.gov/records/GCMD USGS OFR 2007 1104.html.

Vining, K. C., and Vecchia, A. V. (2007). Water-balance simulations of runoff and reservoir storage for the upper Helmand watershed and Kajakai reservoir, central Afghanistan: U.S. Geological Survey Scientific Investigations Report 20075148, 16 p., http://pubs.usgs.gov/sir/2007/5148/.

Vowinkel, E. F., and Tapper, R. J. (1995). Indicators of the sources and distribution of nitrate in water from shallow domestic wells in agricultural areas of the New Jersey coastal plain (Vol. 93, No. 4178). US Department of the Interior, US Geological Survey.

Water Sector Strategy. (2008). Water resources management. Volume II, Pillar III, Infrastructure. Kabul, Afghanistan.

Whitney, J. W. (2006). Geology, water, and wind in the lower Helmand Basin, southern Afghanistan. U.S. Geological Survey Scientific Investigation Report 2006-5182, 40 p., http://pubs.usgs.gov/sir/2006/5182/.

Williams-Sether, T. (2008). Streamflow characteristics of streams in the Helmand Basin, Afghanistan: U.S. Geological Survey Data Series 333, 341 p.

Zhou, Z. (2015). A global assessment of nitrate contamination in groundwater. International Groundwater Resources Assessment Center. Internship report. 